\title{
Prospective Supply and Demand of Medical Technologists in Korea through 2030
}

\author{
Youngho Oh
}

Center for Health Care Research, Department of Health Care Policy Research, Korea Institute for Health \& Social Affairs, Sejong, Korea

\section{임상병리사 인력의 수급전망과 정책방향}

\author{
오영호 \\ 한국보건사회연구원 보건정책연구실 보건의료연구센터
}

\begin{abstract}
The purpose of this study is to provide policy recommendations for manpower planning by forecasting the supply and demand of Medical Technologists. Supply was estimated using an in-and-out movement method with a demographic method based on a baseline projection model. Demand was projected according to a demand-based method using the number of clinicopathologic examinations taken for Medical Technologists. Over- or undersupply of Medical Technologists will depend on the productivity scenario and assumptions and ultimately on governmental policy direction. In other words, whether the production of Medical Technologists is higher or lower than the current level depends on the government policy to consider insurance finances. In this study, we assessed 'productivity scenario 3' based on the productivity as of 2012, when the government's policy direction was not considered. Based on the demand scenario using the ARIMA model, the supply of Medical Technologists is expected to be excessive. This oversupply accounts for less than $10 \%$ of the total and therefore should not be a big problem. However, given that the employment rate of Medical Technologists is $60 \%$, it is necessary to consider policies to utilize the unemployed. These measures should expand the employment opportunities for the unemployed. To this end, it is necessary to strengthen the functions of laboratories in the public health center, to increase the quota of Medical Technologists, to assure their status, to establish a permanent inspection system for outpatient patients, and to expand the export of Medical Technologists overseas.
\end{abstract}

Key words: Demand-based methods, Health workforce policy, Medical Technologist, Projection, Supply and demand

This is an Open Access article distributed under the terms of the Creative Commons Attribution Non-Commercial License (http://creativecommons.org/licenses/by-nc/4.0) which permits unrestricted non-commercial use, distribution, and reproduction in any medium, provided the original work is properly cited.

Copyright () 2018 The Korean Society for Clinical Laboratory Science. All rights reserved.
Corresponding author: Youngho Oh Center for Health Care Research, Department of Health Care Policy Research, Korea Institute for Health \& Social Affairs, Building D (Sejong national research complex), 370 Sicheong-daero, Sejong 30147, Korea Tel: 82-44-287-8202

Fax: 82-44-287-8062

E-mail: ohyho@kihasa.re.kr

Received: September 11, 2018 Revised: September 29, 2018 Accepted: October 3, 2018

\section{서 론}

최근 경제발전으로 인해 국민소득이 증대하고 생활수준이 향상되었으며, 의료기술 발전 및 인구구조 변화 등으로 국민들 의 건강에 대한 기대 상승과 함께 보건의료의 수요는 크게 증가 하여 왔다. 이러한 보건의료 수요의 증가는 보건의료 서비스의 양적인 증가 이외에도 서비스의 종류의 양상에도 변화를 가져
와 새로운 보건인력이 요구되거나 현존하는 보건인력의 공급 변화도 요구되고 있다[1]. 뿐만 아니라 21세기에는 인구 - 경제 • 사회구조의 변화에 따른 의료수요의 다양화 및 의료분야의 첨 단과학화 - 세분화가 예상되어 의료서비스 공급의 중추적 역할 을 담당하고 있는 의료인력 관련 수급문제와 정책은 매우 중요 한 의미를 가지고 있다.

따라서 보건의료서비스의 적정화를 기하기 위하여 보건의료 
인력수급계획 및 정책은 보건의료인력이 충분히 공급되고, 잘 훈련되고, 적절히 분포되고, 그리고 효율적으로 활용될 수 있도 록수립되어야한다[2]. 그러나이러한 취지를 충분히 살린 의료 인력수급은 현실화되지 않고 있으며, 현재 의료인력수급의 정 책적 관심은 수요와 공급의 불균형에 집중되어 있다[3]. 이와 같 은 수급불균형을 해소하여 양질의 보건의료서비스를 보다 안정 적이고 효율적으로 제공하기 위해서는 장래의 사회 변화와 함 께 보건의료 환경의 변화를 예측하고 이에 기초한 보건의료인 력의 적정한 수급계획에 대한 종합적인 연구가 우선적으로 필 요하다[4]. 장래의 사회변화와 보건의료 수요 변화를 감안한 보 건의료인력 수급 준비는 계획적인 인력의 공급뿐 아니라 앞으로 의 보건정책 방향의 지침이 됨으로써 보건정책의 급격한 변화를 방지하여 원활한 보건의료 정책의 수행에 도움이 될 수 있다[5].

또한 보건의료 서비스는 여러 보건관련 분야간의 협력에 의 한 팀 접근으로 이루어지고 있으므로 보건의료인력의 수급계획 은 각각의 인력에 대한 개별적인 접근보다는 관련 보건의료인 력 간의 적합한 비율을 감안함으로써 균형된 보건의료 서비스 를 제공할수 있도록 해야한다. 즉보건의료 수요의 변화와인력간 의 적합한 비율을 감안한 보건의료인력 수급계획은 효율적인 서비 스를 제공할수 있게 하여 보건의료서비스에 대한 소비자의 만족도 를 높일 수 있을 뿐 아니라 인력의 낭비와 비효율적인 공급을 방지 함으로써 비용을 절감하고, 공급된 인력은 효율적으로 관리하게 되 어 전반적으로는 국가의 보건의료비를 절감하게 된다[6-10].

이와 같은 필요성에 따라 의사를 비롯한 보건의료인력 수급 연구는 많이 이루어져 왔지만 지원인력인 의료기사 수급에 관 한 연구는 그 중요성에 비해 상대적으로 미흡하였다. 따라서 본 고에서는 보건의료인력 중 지원인력 중의 하나인 임상병리사 수급전망을 통하여 향후 정책방향의 제시를 목적으로 한다.

\section{재료 및 방법}

\section{1. 수급추계 방법론}

\section{1) 공급추계 방법}

본 연구의 공급추계방법은 임상병리사 인력의 공급을 추계 하기 위해서 기초추계방법(baseline projection method)의 공 급추계 유형을 사용하였고, 추계방법으로는 유입 · 유출법 (method of in-and-out moves)과 인구학적 방법(demographic method)을 사용하였다. 기초추계는 현재의 인력양성 체계를 변화시키지 않는다는 가정 하에서 장래의 인력을 추정 하는 것이고, 유입유출방법은 인력의 재생과정(renewal process) 에 근거를 둔 방법으로서, 변화의 과정을 유입과 유출이라는 두
구성요소로 나누어 추정하는 것이다. 그리고 인구학적 방법은 공급추계 출발연도 각 의료 인력의 총수와 이들의 연령 구조, 그 리고 출발 연도와 목표 연도 간 신규로 증가하거나 손실된 연령 구조에 대한 정보를 통해 목표 연도의 공급 수를 연령별로 추계 하고, 연령별 공급추계치를 합산해서 추정한다[11]. 이에 따라 매연도의 각 의료인력 수는 전년도 인력 수에서 인력 증가분을 더하고 감소분을 감하므로써 계산할 수 있다. 공급추계방법으 로 인구학적인 방법을 함께 사용하는 유입.유출방법은 총수방 법 등의 그 어떤 방법보다 공급추계의 정확성이 높다. 이는 보건 의료인력의 공급은 증가하는 부분과 감소하는 부분이 시간에 따라 다를 수 있는데 이러한 두 요소와 관련한 비교적 정확한 자 료를 확보하여 모두 고려하고 있기 때문이다.

공급추계를 위하여 임상병리사의 면허발급현황, 인력 양성 현황, 가용인력 및 손실인력, 취업현황, 연도별 국가시험 합격률 을 분석하였다. 이 분석결과를 토대로 임상병리사 인력양성과 공급능력추계, 손실수 추계 등을 통하여 인력의 공급전망을 하 였다. 따라서 매연도의 임상병리사 수는 전년도 임상병리사수 에서 증가분을 더하고 감소분을 감하므로써 계산할 수 있다. 본 연구에서 사용한 공급추계 모형은 다음과 같다(Figure 1).

\section{2) 수요추계 방법}

본 연구의 수요추계방법은 수요추계에 사용되는 자료의 가 용성에 따라 달라지는데, 의료인력이 제공하는 의료서비스의

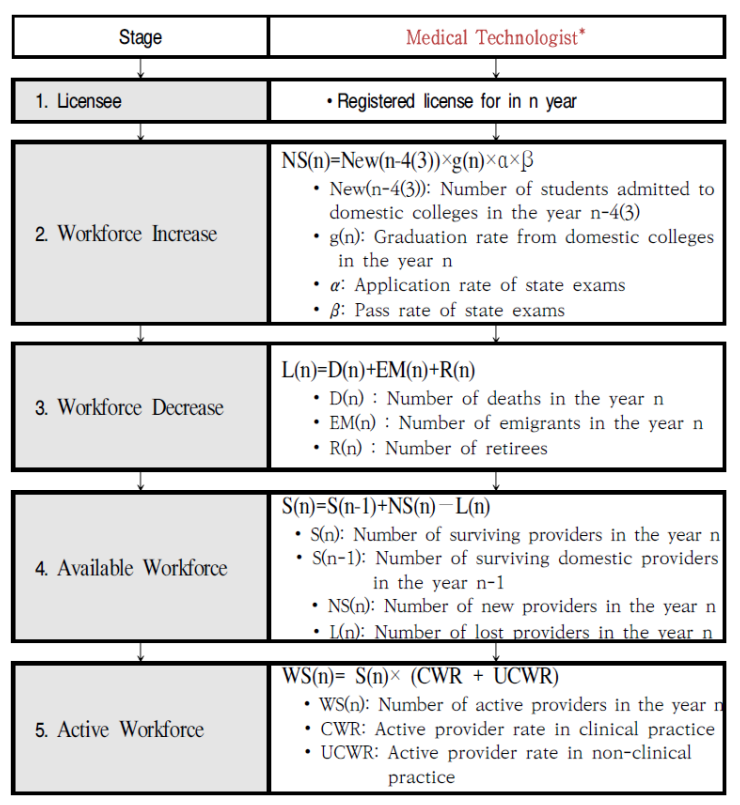

Figure 1. Health care workforce supply projection model. *Synonyms: Medical Laboratory Technologist, Clinical Laboratory Technologist, Medical Laboratory Scientist, Clinical Laboratory Scientist. 
양에 관한 객관적인 자료를 수집할 수 있는 경우 의료수요에 근 거한 방법(demand-based method)을 주로 사용한다[12]. 따 라서 임상병리사 인력 수요추계에서는 객관적인 자료를 수집할 수 있기 때문에 의료수요에 근거한 인력수요 추계방법론 중 미 국의 보건자원 및 서비스국 (HRSA, Health Resources and Services Administration)의 BHPr (Bureau of Health Professions)에서 사용한 의료수요에 근거한 인력수요 추계방 법론을 적용하였다[13]. 이 모형은 인구구조 및 인구규모의 변 화와 의료보장적용의 변화, 그밖에 의료이용에 영향을 미칠 수 있는 다양한 요인들을 고려할 수 있도록 고안된 것으로, 다음 그 림에서 수요에 근거한 추계방법에 대한 각 의료인력의 추계과 정을 볼 수 있다(Figure 2). 본 연구에서 임상병리사의 임상병리 검사건수의 추세를 추계하기 위한 통계적인 모델로 선형모형 중에서는 기하평균을 적용한 평균증가율방법을, 곡선모형 중 에서 의료이용증가추세에 적합한 로지스틱 함수(logistic)와 로 그(logarithmic)함수를[14], 시계열 분석방법 중에서는 시계열 분석은 Box \& Jenkins유형의 ARIMA (Autoregressive Integrated Moving Average) 모델을 적용하였다[15].

\section{2. 수급추계 자료 및 가정}

\section{1) 연구자료}

임상병리사 공급추계를 위해 사용된 자료는 교육인적자원 부, 보건복지부, 대한임상병리사협회, 한국보건의료인국가시 험원 등으로부터 임상병리사 공급추계에 필요한 연도별 입학정 원, 졸업자수, 면허등록현황, 국가시험 재응시자 수, 취업자
수 등의 자료를 수집하여 분석하였으며, 수요추계를 위한 자 료 중 입원 및 외래의료이용에 관한 자료는 건강보험심사평가 원으로부터 확보하였으며, 장래인구 추계치는 통계청으로부 터 수집하였다.

\section{2) 추계에 사용된 가정}

공급추계에서 적용한 가정은 다음과 같다. 첫째, 신규 배출 임상병리사의 $\mathrm{N}$ 년도의 임상병리학과 입학생수에 대한 자료가 명확하지가 않아 입학정원과 입학 외 정원을 포함한 정원을 입 학생수로 간주하였다. 또한 졸업자수에 대한 자료도 불분명하 여 졸업생수는 휴학, 복학, 퇴학 등 재학 중 여러 가지 사유로 인 하여 입학정원과 다른 양상을 보일 수 있지만 본 연구에서는 $\mathrm{N}-4(3)$ 년도의 입학정원이 모두 졸업하는 것으로 간주하였으 며, 국가시험 응시자는 N년도 졸업자와 N-(1)년도 시험 불합격 자가 모두 응시하는 것으로 간주하였다. 둘째, 손실 임상병리사 수는 사망자, 은퇴자, 해외 이주자를 합한 수로 계산된다. 본 연 구에서 임상병리사 인력의 사망률은 연령별 사망률을 적용하였 다. 그리고 2012년까지 61세 이상 의료인력 중 비활동자를 은 퇴자로 일시에 제외하였으며, 향후 목표연도까지는 61세 이상 인력을 제외한 가용인력 중에서 60세의 비율을 은퇴비율로 적 용하였다. 임상병리사 인력의 해외이주자도 2012년까지의 해 외이주자는 제외하였고, 향후 목표연도까지의 해외 이주율은 최근 5년간 한해 배출되는 인력 중에서 평균 해외 이주율을 추 정하여 적용하였다. 이러한 가정 하에 본 연구에서는 면허등록 의료인력, 가용의료인력, 활동의료인력, 그리고 임상부문과 비

\begin{tabular}{|c|c|c|c|}
\hline Step & Variables & Equation & Description \\
\hline \multirow[t]{4}{*}{$\begin{array}{l}\text { Base year } \\
\text { utilization }\end{array}$} & Utilization rate & 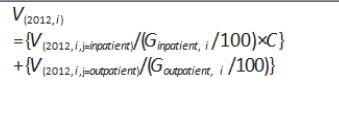 & $\begin{array}{l}V_{(2012, j)}: 2012 \text { Utilization rate } \\
G_{(i, i)}: \text { Insurance distribution ratio } \\
C: \text { Inpatient-outpatient conversion ratio } \\
i: \text { Type of medical worker }\end{array}$ \\
\hline & Weighted utilization & $\begin{array}{l}W_{(2012, i)} \\
=\left(U_{(2012, i)} / P_{(2012, i)} \div\left(\sum U_{(2012, i}\right) \sum P_{(2012, i)}\right)\end{array}$ & $\begin{array}{l}j: \text { Type of medical service } \\
W_{(2012,1}: \text { Weighted utilization byage }\end{array}$ \\
\hline & $\begin{array}{l}\text { Adjustedutilization } \\
\text { rate percapita }\end{array}$ & $\begin{array}{l}R_{(2012, i)} \\
=V_{(2012, i)} \div W P_{2012} \\
=V_{(2012, i)} \div \sum\left(W_{(2012,1)} \times P_{(2012,1)}\right)\end{array}$ & $\begin{array}{l}U_{(2012,1:}: \text { Utilization by age } \\
P_{(2012,1):} \text { Population by age } \\
i: \text { Age }\end{array}$ \\
\hline & & & $\begin{array}{l}R_{(2012, i):}: 2012 \text { Adjusted per capita utilization } \\
W P_{2012}: 2012 \text { Total adjusted population }\end{array}$ \\
\hline $\begin{array}{l}\text { Target year } \\
\text { utilization }\end{array}$ & Utilization & $\begin{array}{l}V_{(n, i)} \\
=\left(R_{(2012, i)} \times W P_{n}\right) \times(1+1-\mathrm{OAGE}) \\
=R_{(2012, i)} \times \sum\left(W_{(2012,1)} \times P_{(n, 1)}\right) \times\left(1+\left(l_{i}-\mathrm{OAGE}\right)\right)\end{array}$ & $\begin{array}{l}V_{(n, i)}: \text { Year n utilization } \\
R_{(n, i)}: \text { Year } n \text { utilization based on growth rate } \\
W P_{n}: \text { Adjusted total population } \\
l_{i}: \text { Utilization growth rate } \\
\text { OAGE: Affect of aging on utilization growth }\end{array}$ \\
\hline \multirow[t]{5}{*}{$\begin{array}{l}\text { Target year } \\
\text { supply \& demand }\end{array}$} & Productivity & $\begin{array}{l}D P_{(2012, i)} \\
=\mathrm{R}_{(2012, i)} T \mathbb{T H} M_{(2012, i)}\end{array}$ & $\begin{array}{l}D P_{(2012, i)}: \text { Productivity } \\
T H M_{(2012, i)} \text { :Total number of medical worker }\end{array}$ \\
\hline & Number of dinical workers & $N D_{[n, i]}$ & $N D_{(n, i)}:$ Year n number of dinical workers \\
\hline & & $=\mathrm{V}_{(n, i)} / D P_{(2012, i)} / W D$ & $\begin{array}{l}\text { WD : Working days a year } \\
U N D_{n} ;: \text { Yearn number of non-clinical workers }\end{array}$ \\
\hline & $\begin{array}{l}\text { Number of non-dinical } \\
\text { workers }\end{array}$ & $\begin{array}{l}U N D_{(n i)} \\
=N D_{n i} \times\left(N N D R_{2012, i} / N D R_{(2012, i]}\right)\end{array}$ & $\begin{array}{l}N D R_{(2012)}: \text { Clinical worker ratio } \\
N N D R_{(2012):} \text { Non-clinical worker ratio }\end{array}$ \\
\hline & Total number of workers & $\begin{array}{l}T N D_{(n, i)} \\
=N D_{(n, i)}+N N D_{(n, i)}\end{array}$ & $\begin{array}{l}T N D_{(n, i)} \text { : Total number of medical workers } \\
N D_{(n, i)} \text { : Clinical medical workers } \\
N N D_{(n, i)} \text { : Non-clinical medical workers }\end{array}$ \\
\hline
\end{tabular}

Figure 2. Health care workforce demand projection model. 
임상 부분의 의료 인력을 추계하였다. N년도의 의료 인력은 $\mathrm{N}-1$ 연도의 의료 인력수에 N년도의 의료인력 증가수를 더하고 $\mathrm{N}$ 년도의 손실 의료 인력수를 제외하면 된다.

수요를 추계하는데 사용된 가정은 다음과 같다. 첫째, 목표연 도의 인구는 연령별 의료이용의 차이를 반영하는 연령가중치가 적용된 보정된 인구수를 적용하였다. 이때 장래추계인구수는 통 계청에서 발표한 자료를 이용하였고, 의료이용가중치는 2012 년 건강보험심사평가원 내부 자료를 협조 받아 재분석하여 산출 한 가중치를 적용하였다. 둘째, 임상병리검사건수추세는 2003 년부터 2012년까지 건강보험과 의료급여 대상자의 인구 1 인당 외래 임상병리검사건수와 입원 임상병리검사건수 자료를 사용 하여 평균증가율방법과 곡선추정회귀모형(Curve Estimation Regression Model)에서 로지스틱 함수와 로그함수를 적용한 방법과 시계열 분석방법에서 ARIMA모형을 적용한 방법으로 목 표연도의 1 인당 임상병리검사건수를 추정하였다. 셋째, 임상병 리사의 생산성인 임상병리사 1일 임상병리검사건수는 2012년 이용량을 적용하여 265 일 근무하는 것으로 가정하여 추정하였 으며, 임상병리사 1 인당 임상병리검사건수는 246.98 로 추정되 었다. 그리고 임상병리사의 근무일수는 의료인력 수급추계에서 가장 많이 사용되는 265 일과 255 일을 적용하였다. 265 일은 법 정 공휴일, 일요일, 토요일, 등을 감안할 경우로, Park [16]의 연 구도 이 수치의 사용을 지지하고 있으며, 255일은 265일에 학술 대회나학회 참석 등의 휴진일수를 감안한 일수 이다[17]. 넷째, 의료인력 수요 추계시 입원환자의 서비스수요량을 외래환자 서 비스수요량으로 환산하는데 있어서는 입원환자와 외래환자에 투입되는 의료 인력의 노력과 시간의 상대적 비율을 고려하여야 하지만, 임상병리검사의 경우는 입원환자와 외래환자에 차이가 없기 때문에 환산 비를 적용하지 않았다.

Table 1. Annual status of successful and licensed registrants of Medical Technologist by year (Units: person; \%)

\begin{tabular}{ccccc}
\hline Year & $\begin{array}{c}\text { No.of } \\
\text { applicants }\end{array}$ & $\begin{array}{c}\text { No. of } \\
\text { applicants } \\
\text { accepted }\end{array}$ & $\begin{array}{c}\text { No. of } \\
\text { Rate of } \\
\text { exam pass }\end{array}$ & $\begin{array}{c}\text { accumulated } \\
\text { applicants } \\
\text { accepted }\end{array}$ \\
\hline 2005 & 2,269 & 1,400 & 61.7 & 36,982 \\
2006 & 2,365 & 1,375 & 58.1 & 38,358 \\
2007 & 2,366 & 1,440 & 60.9 & 39,794 \\
2008 & 2,395 & 1,225 & 51.1 & 41,019 \\
2009 & 2,654 & 1,708 & 64.4 & 42,727 \\
2010 & 2,371 & 1,202 & 50.7 & 43,929 \\
2011 & 2,497 & 1,618 & 64.8 & 45,547 \\
2012 & 2,482 & 1,496 & 60.3 & 47,043 \\
2013 & 2,756 & 1,798 & 65.2 & 48,841 \\
\hline
\end{tabular}

Source: Korea Health Personnel Licensing Examination Institute, 2013.

\section{결 과}

임상병리사는 병리학, 미생물학, 생화학, 기생충학, 혈액학, 혈청학, 법의학, 요화학, 세포 병리학, 방사선 동위원소를 사용 한 가검물등의 검사 및 생리학적 검사의 분야에서 임상병리 검 사 업무에 필요한 기계, 기구, 시약 등의 보관, 관리, 사용, 가검 물 등의 채취, 검사 검사용시약의 조제, 혈액의 채혈, 제제, 제조, 조작, 보존, 공급, 기타 임상병리검사 업무에 종사한다고 되어 있다. 최근 이러한 업무를 수행할 인력을 공급하기 위한 임상병 리사 인력이 과잉 배출되고 있다는 지적이 있었다. 따라서 이 장 에서는 현재의 임상병리사 수급현황을 파악하고 장래의 수요와 공급을 예측하여, 향후 임상병리사 수급전망을 통하여 임상병 리사 인력수급정책의 기초자료를 제시하고자 한다.

\section{1. 인력 공급분석 및 공급추계}

\section{1) 공급분석}

2013년 임상병리사 국가시험 시험응시자수는 2,756명이며 이 중 1,798 명이 시험에 합격하여 $65.2 \%$ 의 합격률을 보였다. 2013년 말 전체 면허등록자는 48,841명으로 2005년의 36,982 명에 비하여 약 1.32 배 증가하였다(Table 1). 한편 2013 년 임상병리사 관련학과 입학정원은 3년제 1,780 명, 4 년제 1,082 명으로 총 입학정원은 2,862명이다. 정원외 입학은 4년 제와 3년제를 합하여 총 266명이다(Table 2).

\section{2) 공급추계}

임상병리사 공급추계유형은 기초추계방법을 사용하였고, 추계방법으로는 인구학적인 방법과 유입유출방법을 적용하였 다. 앞서 언급한추계가정들과 기초 자료를 적용한 2030년까지

Table 2. Current status of training related departments of Medical Technologist (Unit: person)

\begin{tabular}{cccccc}
\hline \multirow{2}{*}{ Year } & \multicolumn{2}{c}{ 4-year college } & & \multicolumn{2}{c}{ 3-year college } \\
\cline { 2 - 3 } \cline { 5 - 6 } & $\begin{array}{c}\text { Admission } \\
\text { quota }\end{array}$ & $\begin{array}{c}\text { Other than } \\
\text { quota }\end{array}$ & & $\begin{array}{c}\text { Admission } \\
\text { quota }\end{array}$ & $\begin{array}{c}\text { Other than } \\
\text { quota }\end{array}$ \\
\hline 2005 & 407 & 23 & & 1,760 & 100 \\
2006 & 477 & 27 & & 1,880 & 107 \\
2007 & 597 & 34 & & 1,940 & 111 \\
2008 & 627 & 42 & & 1,720 & 143 \\
2009 & 707 & 61 & & 1,730 & 185 \\
2010 & 887 & 91 & & 1,690 & 244 \\
2011 & 932 & 93 & & 1,720 & 239 \\
2012 & 902 & 75 & & 1,750 & 218 \\
2013 & 1,082 & 77 & & 1,780 & 189 \\
\hline
\end{tabular}

Source: Ministry of Health and Welfare, 2013. 
의 임상병리사 인력 추계결과는 다음과 같다. 면허등록자에서 사망자와 해외이주자 그리고 은퇴자를 제외한 가용인력은 2015년에 43,986명, 2020년에 58,238명, 2025년에 71,210 명, 2030년에 82,107명으로 나타났으며, 의료부문과 비의료 부문을 합한 활동인력공급은 2015년에 25,776명, 2020년에 34,128명, 2025년에 41,747명, 2030년에 48,115명으로 전망 된다(Table 3).

\section{2. 인력수요분석 및 수요추계}

\section{1) 수요분석}

임상병리의 의료보장종류별 연령별 의료이용인 임상병리건 수의 가중치 결과는 아래 표와 같다. 25 34세를 기준으로 살펴 보면, 건강보험 외래의 경우 65 74세 연령층은 3.5배, 75세 이 상 연령층의 경우는 의료이용이 2.8 배 높았다. 건강보험 입원의 경우 65 74세 연령층은 7.7배, 75세 이상 연령층은 11.4 배의 의료이용을 보였다. 의료급여의 경우 외래에서 $0 \sim 4$ 세와 75 세 이상을 제외하고는 연령층이 높아질수록 상대적으로 의료이용 가중치가 높아지고 있다(Table 4).

임상병리사가 제공하는 외래환자의 임상병리검사건수는 지 난 2008년부터 2012년 5년간 건강보험은 32.3\%, 의료급여는 $35.4 \%$ 의 증가율을 보이고 있다. 입원에서는 지난 2008년부터

Table 3. Projection of the supply of Medical Technologist (Unit: person)

\begin{tabular}{cccccc}
\hline Year & $\begin{array}{c}\text { Licensed } \\
\text { supply }\end{array}$ & $\begin{array}{c}\text { Available } \\
\text { supply }\end{array}$ & $\begin{array}{c}\text { Active } \\
\text { supply }\end{array}$ & Clinical & Nonclinical \\
\hline 2015 & 53,988 & 43,986 & 25,776 & 19,874 & 5,902 \\
2020 & 69,190 & 58,238 & 34,128 & 26,314 & 7,814 \\
2025 & 84,770 & 71,240 & 41,747 & 32,189 & 9,558 \\
2030 & 100,354 & 82,107 & 48,115 & 37,098 & 11,016 \\
\hline
\end{tabular}

Table 4. Weight and number of clinical pathology tests by age and type of health insurance (2012)

\begin{tabular}{cccccc}
\hline \multirow{2}{*}{$\begin{array}{c}\text { Age } \\
\text { group } \\
\text { (year) }\end{array}$} & \multicolumn{2}{c}{ National Health Insurance } & & \multicolumn{2}{c}{ Medical Care } \\
\cline { 2 - 3 } \cline { 5 - 6 } & $\begin{array}{c}\text { Outpatient } \\
\text { utilization }\end{array}$ & $\begin{array}{c}\text { Inpatient } \\
\text { utilization }\end{array}$ & & $\begin{array}{c}\text { Outpatient } \\
\text { utilization }\end{array}$ & $\begin{array}{c}\text { Inpatient } \\
\text { utilization }\end{array}$ \\
\hline $0 \sim 4$ & 0.44 & 1.38 & 0.23 & 0.36 \\
$5 \sim 14$ & 0.25 & 0.25 & 0.18 & 0.12 \\
$15 \sim 24$ & 0.35 & 0.27 & 0.26 & 1.41 \\
$25 \sim 34$ & 0.71 & 0.39 & 0.76 & 0.49 \\
$35 \sim 44$ & 0.77 & 0.50 & 1.06 & 0.73 \\
$45 \sim 54$ & 1.20 & 0.91 & 1.31 & 1.05 \\
$55 \sim 64$ & 1.87 & 1.60 & 1.51 & 1.19 \\
$65 \sim 74$ & 2.49 & 2.99 & 1.59 & 1.10 \\
$75+$ & 2.00 & 4.45 & 1.17 & 1.22 \\
\hline
\end{tabular}

Source: 2012 Health Insurance Review Agency's internal data.
2012년 5년간 건강보험과 의료급여의 임상병리검사건수가 각 각 $28.4 \%, 62.0 \%$ 로 증가하였으며 건강보험환자에 비해 의료급 여환자의 검사건수증가율이 약 2.2 배 높은 것으로 나타났다 (Table 5).

\section{2) 수요추계}

전체 임상병리사 인력의 수요는 환자의 의료이용량인 임상 병리검사건수에 근거하여 추계한 임상 임상병리사수요와교육· 행정 · 연구 등에 종사하는 비임상 임상병리사 인력 수요를 합 산하여 산출된다. 먼저 종합병원, 병원, 의원 등의 의료기관에서 종사하는 임상 임상병리사 인력이 제공하는 의료이용으로부터 파생되는 임상 임상병리사 인력수요를 추계하고 이를 근거로 비임상 임상병리사 인력수요를 추계한다.

(1) 임상부문 임상병리사 수요

임상병리사의 경우 근무가능일수 255 일을 기준으로 하였다. 첫째, 평균증가율(Increase rate of geometric average) 을 적 용하여 추정한 수요추계결과를 살펴보면, 생산성에 따라 2015 년에 적게는 17,485 명에서 많게는 27,256 명이 필요할 것으로 전망되었고, 2030년에는 적게는 51,626명에서 많게는 80,476 명이 필요할 것으로 전망되었다(Table 6). 둘째, Curve Estimation 방법중로짓함수모형을 적용하여 추정한 수요추계결과를 살펴 보면, 생산성에 따라 2015년에 적게는 19,691명에서 많게는 29,537 명이 필요할 것으로 전망되었고, 2030년에는 적게는 68,934 명에서 많게는 103,402 명이 필요할 것으로 전망되었다 (Table 7). 셋째, Logarithm모형으로 추정한 수요추계결과를 살펴보면, 생산성에 따라 2015년에 적게는 17,580 명에서 많게 는 26,371명이 필요할 것으로 전망되었고, 2030년에는 적게는 35,186 명에서 많게는 52,779 명이 필요할 것으로 전망되었다 (Table 8). 넷째, ARIMA모형으로 추정한 수요추계결과를 살펴 보면, 생산성에 따라 2015년에 적게는 16,979 명에서 많게는

Table 5. Number of annual clinical pathology tests per healthcare covered population

\begin{tabular}{cccccc}
\hline \multirow{2}{*}{ Year } & \multicolumn{2}{c}{ National Health Insurance } & & \multicolumn{2}{c}{ Medical Care } \\
\cline { 2 - 3 } \cline { 5 - 6 } & $\begin{array}{c}\text { Outpatient } \\
\text { utilization }\end{array}$ & $\begin{array}{c}\text { Inpatient } \\
\text { utilization }\end{array}$ & & $\begin{array}{c}\text { Outpatient } \\
\text { utilization }\end{array}$ & $\begin{array}{c}\text { Inpatient } \\
\text { utilization }\end{array}$ \\
\hline 2008 & 7.876 & 7.766 & & 15.741 & 30.816 \\
2009 & 8.730 & 8.282 & & 17.568 & 34.279 \\
2010 & 9.198 & 9.256 & & 17.858 & 34.477 \\
2011 & 9.833 & 9.399 & & 19.563 & 36.041 \\
2012 & 10.423 & 9.970 & & 21.312 & 49.926 \\
\hline
\end{tabular}

Notes: Outpatient utilization, No. of outpatient visits; Inpatient utilization, length of stay.

Source: 2012 Health Insurance Review Agency's internal data. 
516 Youngho Oh. Forecasting of Supply and Demand of Medical Technologists through 2030

Table 6. Demand 1 (Increase rate of geometric average): Medical Technologist (Unit: persons)

\begin{tabular}{lcccccccc}
\hline Working days (Clinical) & \multicolumn{9}{c}{255 days } \\
\hline Year & 2015 & 2020 & 2025 & 2030 & 2015 & 2020 & 2025 & 2030 \\
Productivity scenario 1 & 18,170 & 26,238 & 37,650 & 53,651 & 17,485 & 25,248 & 36,229 & 51,626 \\
Productivity scenario 2 & 19,822 & 28,624 & 41,073 & 58,528 & 19,074 & 27,544 & 39,523 & 56,320 \\
Productivity scenario 3 & 21,804 & 31,486 & 45,180 & 64,381 & 20,982 & 30,298 & 43,475 & 61,952 \\
Productivity scenario 4 & 24,227 & 34,985 & 50,200 & 71,535 & 23,313 & 33,664 & 48,306 & 68,835 \\
Productivity scenario 5 & 27,256 & 39,358 & 56,475 & 80,476 & 26,227 & 37,873 & 54,344 & 77,440 \\
\hline
\end{tabular}

Table 7. Demand 2 (Logistic): Medical Technologist (Unit: persons)

\begin{tabular}{|c|c|c|c|c|c|c|c|c|}
\hline \multirow{2}{*}{$\begin{array}{l}\text { Working days (Clinical) } \\
\text { Year }\end{array}$} & \multicolumn{4}{|c|}{255 days } & \multicolumn{4}{|c|}{265 days } \\
\hline & 2015 & 2020 & 2025 & 2030 & 2015 & 2020 & 2025 & 2030 \\
\hline Productivity scenario 1 & 19,691 & 30,202 & 45,905 & 68,934 & 18,948 & 29,062 & 44,172 & 66,333 \\
\hline Productivity scenario 2 & 21,481 & 32,947 & 50,078 & 75,201 & 20,671 & 31,704 & 48,188 & 72,363 \\
\hline Productivity scenario 3 & 23,629 & 36,242 & 55,086 & 82,721 & 22,738 & 34,874 & 53,007 & 79,600 \\
\hline Productivity scenario 4 & 26,255 & 40,269 & 61,206 & 91,913 & 25,264 & 38,749 & 58,896 & 88,444 \\
\hline Productivity scenario 5 & 29,537 & 45,303 & 68,857 & 103,402 & 28,422 & 43,593 & 66,259 & 99,500 \\
\hline
\end{tabular}

Table 8. Demand 3 (Logarithm): Medical Technologist (Unit: persons)

\begin{tabular}{lcccccccc}
\hline Working days (Clinical) & \multicolumn{9}{c}{255 days } \\
\hline Year & 2015 & 2020 & 2025 & 2030 & 2015 & 2020 & 2025 & 2030 \\
Productivity scenario 1 & 17,580 & 23,038 & 28,966 & 35,186 & 16,917 & 22,168 & 27,873 & 33,858 \\
Productivity scenario 2 & 19,179 & 25,132 & 31,599 & 38,385 & 18,455 & 24,183 & 30,407 & 36,936 \\
Productivity scenario 3 & 21,096 & 27,645 & 34,759 & 42,223 & 20,300 & 26,602 & 33,447 & 40,630 \\
Productivity scenario 4 & 23,441 & 30,717 & 38,621 & 46,915 & 22,556 & 29,558 & 37,164 & 45,144 \\
Productivity scenario 5 & 26,371 & 34,556 & 43,449 & 52,779 & 25,375 & 33,252 & 41,809 & 50,787 \\
\hline
\end{tabular}

Table 9. Demand 4 (ARIMA): Medical Technologist (Unit: persons)

\begin{tabular}{|c|c|c|c|c|c|c|c|c|}
\hline \multirow{2}{*}{$\begin{array}{l}\text { Working days (Clinical) } \\
\text { Year }\end{array}$} & \multicolumn{4}{|c|}{255 days } & \multicolumn{4}{|c|}{265 days } \\
\hline & 2015 & 2020 & 2025 & 2030 & 2015 & 2020 & 2025 & 2030 \\
\hline Productivity scenario 1 & 16,979 & 21,325 & 25,444 & 29,103 & 16,338 & 20,520 & 24,484 & 28,005 \\
\hline Productivity scenario 2 & 18,523 & 23,263 & 27,757 & 31,749 & 17,824 & 22,385 & 26,710 & 30,551 \\
\hline Productivity scenario 3 & 20,375 & 25,590 & 30,533 & 34,923 & 19,606 & 24,624 & 29,381 & 33,606 \\
\hline Productivity scenario 4 & 22,639 & 28,433 & 33,926 & 38,804 & 21,785 & 27,360 & 32,646 & 37,340 \\
\hline Productivity scenario 5 & 25,469 & 31,987 & 38,167 & 43,654 & 24,508 & 30,780 & 36,726 & 42,007 \\
\hline
\end{tabular}

25,469명이 필요할 것으로 전망되었고, 2030년에는 적게는 29,103 명에서 많게는 43,654명이 필요할 것으로 전망되었다 (Table 9). 시나리오와는 무관하게 근무가능일수를 265일을 기 준으로 하면 255일에 비해 필요임상병리사수가 $3.8 \%$ 정도 줄어 드는 것으로 나타났다.

(2) 비임상 임상병리사 수요

임상분야를 제외한 비임상 분야로는 교육, 행정·연구 등을 들 수 있는데, 먼저 임상분야의 임상병리사 수요추계결과에 비임 상 임상병리사 비율인 29.7\% [7]를 적용한 비임상 임상병리사 수요추계결과, 임상분야의 임상병리사 수요추계에서 사용한
근무가능일수 255 일을 기준으로 하였다.

첫째, 평균증가율(Increase rate of geometric average) 을 적 용하여 추정한 수요추계결과를 살펴보면, 생산성에 따라 2015년 에 적게는 5,192명에서 많게는 8,094명이 필요할 것으로 전망되었 고, 2030년에는 적게는 15,330 명에서 많게는 23,897명이 필요할 것으로 전망되었다(Table 10). 둘째, Curve Estimation 방법 중로 짓함수모형을 적용하여 추정한 수요추계결과를 살펴보면, 2015년 에 적게는 5,847 명에서 많게는 8,771 명의 비임상 임상병리사 인력 이 필요할 것으로 나타났고, 2030년에는 적게는 20,470명에서 많 게는 30,705 명의 비임상 임상병리사 인력이 필요할 것으로 전망된 
Table 10. Demand 1 (Increase rate of geometric average): non-clinical Medical Technologist (Unit: persons)

\begin{tabular}{lcccccccc}
\hline $\begin{array}{c}\text { Working days } \\
\text { (Non-Clinical) }\end{array}$ & \multicolumn{9}{c}{255 days } \\
\hline Year & 2015 & 2020 & 2025 & 2030 & 2015 & 2020 & 2025 & 2030 \\
Productivity scenario 1 & 5,396 & 7,792 & 11,180 & 15,932 & 5,192 & 7,497 & 10,758 & 15,330 \\
Productivity scenario 2 & 5,886 & 8,500 & 12,197 & 17,380 & 5,664 & 8,179 & 11,736 & 16,724 \\
Productivity scenario 3 & 6,475 & 9,350 & 13,416 & 19,118 & 6,231 & 8,997 & 12,910 & 18,397 \\
Productivity scenario 4 & 7,194 & 10,389 & 14,907 & 21,242 & 6,923 & 9,997 & 14,344 & 20,441 \\
Productivity scenario 5 & 8,094 & 11,687 & 16,770 & 23,897 & 7,788 & 11,246 & 16,137 & 22,996 \\
\hline
\end{tabular}

Table 11. Demand 2 (Logistic): non-clinical Medical Technologist (Unit: persons)

\begin{tabular}{lcccccccc}
\hline $\begin{array}{c}\text { Working days } \\
\text { (Non-Clinical) }\end{array}$ & \multicolumn{9}{c}{255 days } \\
\hline Year & 2015 & 2020 & 2025 & 2030 & 2015 & 2020 & 2025 & 2030 \\
Productivity scenario 1 & 5,847 & 8,968 & 13,631 & 20,470 & 5,627 & 8,630 & 13,117 & 19,698 \\
Productivity scenario 2 & 6,379 & 9,784 & 14,871 & 22,331 & 6,138 & 9,415 & 14,309 & 21,488 \\
Productivity scenario 3 & 7,017 & 10,762 & 16,358 & 24,564 & 6,752 & 10,356 & 15,740 & 23,637 \\
Productivity scenario 4 & 7,796 & 11,958 & 18,175 & 27,293 & 7,502 & 11,507 & 17,489 & 26,263 \\
Productivity scenario 5 & 8,771 & 13,453 & 20,447 & 30,705 & 8,440 & 12,945 & 19,675 & 29,546 \\
\hline
\end{tabular}

Table 12. Demand 3 (Logarithm): non-clinical Medical Technologist (Unit: persons)

\begin{tabular}{lcccccccc}
\hline $\begin{array}{c}\text { Working days } \\
\text { (Non-Clinical) }\end{array}$ & \multicolumn{9}{c}{255 days } \\
\hline Year & 2015 & 2020 & 2025 & 2030 & 2015 & 2020 & 2025 & 2030 \\
Productivity scenario 1 & 5,220 & 6,841 & 8,601 & 10,448 & 5,023 & 6,583 & 8,277 & 10,054 \\
Productivity scenario 2 & 5,695 & 7,463 & 9,383 & 11,398 & 5,480 & 7,181 & 9,029 & 10,968 \\
Productivity scenario 3 & 6,265 & 8,209 & 10,322 & 12,538 & 6,028 & 7,899 & 9,932 & 12,065 \\
Productivity scenario 4 & 6,961 & 9,121 & 11,469 & 13,931 & 6,698 & 8,777 & 11,036 & 13,406 \\
Productivity scenario 5 & 7,831 & 10,261 & 12,902 & 15,673 & 7,535 & 9,874 & 12,415 & 15,081 \\
\hline
\end{tabular}

다. 그리고 활동일수가 265일 기준으로 2015년에 적게는 5,627명 에서 많게는 8,440명의 비임상 임상병리사가 필요한 것으로 전망 되었으며, 2030년에는 적게는 19,698명에서 많게는 29,546명의 비임상 임상병리사가 필요할 것으로 전망되었다(Table 11).

셋째, Logarithm모형으로 추정한 수요추계결과를 살펴보 면, 2015년에 적게는 5,220명에서 많게는 7,831명의 비임상 임상병리사 인력이 필요할 것으로 나타났고, 2030년에는 적게 는 10,448 명에서 많게는 15,673 명의 비임상 임상병리사 인력 이 필요할 것으로 전망된다. 그리고 활동일수가 265일 기준으 로 2015년에 적게는 5,023명에서 많게는 7,535명의 비임상 임 상병리사가 필요한 것으로 전망되었으며, 2030년에는 적게는 10,054 명에서 많게는 15,081 명의 비임상 임상병리사가 필요 할 것으로 전망되었다(Table 12).

넷째, ARIMA모형으로 추정한 수요추계결과를 살펴보면, 2015년에 적게는 5,042명에서 많게는 7,563명의 비임상 임상 병리사 인력이 필요할 것으로 나타났고, 2030년에는 적게는
8,642 명에서 많게는 12,963 명의 비임상 임상병리사 인력이 필 요할 것으로 전망된다. 그리고 활동일수가 265일 기준으로 2015년에 적게는 4,852명에서 많게는 7,278명의 비임상 임상 병리사가 필요한 것으로 전망되었으며, 2030년에는 적게는 8,316 명에서 많게는 12,474 명의 비임상 임상병리사가 필요할 것으로 전망되었다(Table 13).

(3) 총 임상병리사 수요

전체 임상병리사인력의 수요는 환자의 의료수요에 근거하여 추계한 임상병리사 인력 수요와 교육 - 행정 - 연구 등에 종사하 는 비임상 분야의 임상병리사 인력 수요를 합산하여 산출된다. 합산된 임상분야의 임상병리사 인력수요는 아래 표와 같다. 근 무가능일수 255일을 기준으로 하였다. 첫째, 평균증가율(Increase rate of geometric average) 을 적용하여 추정한 수요추계결과를 살펴보면, 생산성에 따라 2015년에 적게는 22,677명에서 많게 는 35,349명이 필요할 것으로 전망되었고, 2030년에는 적게는 66,957 명에서 많게는 104,374 명이 필요할 것으로 전망되었다 
518 Youngho Oh. Forecasting of Supply and Demand of Medical Technologists through 2030

Table 13. Demand 4 (ARIMA): non-clinical Medical Technologist (Unit: persons)

\begin{tabular}{lcccccccc}
\hline $\begin{array}{c}\text { Working days } \\
\text { (Non-Clinical) }\end{array}$ & \multicolumn{9}{c}{255 days } \\
\hline Year & 2015 & 2020 & 2025 & 2030 & 2015 & 2020 & 2025 & 2030 \\
Productivity scenario 1 & 5,042 & 6,332 & 7,556 & 8,642 & 4,852 & 6,093 & 7,271 & 8,316 \\
Productivity scenario 2 & 5,500 & 6,908 & 8,243 & 9,428 & 5,293 & 6,647 & 7,932 & 9,072 \\
Productivity scenario 3 & 6,050 & 7,599 & 9,067 & 10,370 & 5,822 & 7,312 & 8,725 & 9,979 \\
Productivity scenario 4 & 6,723 & 8,443 & 10,074 & 11,523 & 6,469 & 8,125 & 9,694 & 11,088 \\
Productivity scenario 5 & 7,563 & 9,499 & 11,334 & 12,963 & 7,278 & 9,140 & 10,906 & 12,474 \\
\hline
\end{tabular}

Table 14. Demand 1 (Increase rate of geometric average): Total Medical Technologist (Unit: persons)

\begin{tabular}{lcccccccc}
\hline \multicolumn{1}{c}{ Working days (Active) } & \multicolumn{4}{c}{255 days } \\
\hline Year & 2015 & 2020 & 2025 & 2030 & 2015 & 2020 & 2025 & 2030 \\
Productivity scenario 1 & 23,566 & 34,030 & 48,830 & 69,583 & 22,677 & 32,746 & 46,988 & 66,957 \\
Productivity scenario 2 & 25,708 & 37,124 & 53,269 & 75,908 & 24,738 & 35,723 & 51,259 & 73,044 \\
Productivity scenario 3 & 28,279 & 40,836 & 58,596 & 83,499 & 27,212 & 39,295 & 56,385 & 80,348 \\
Productivity scenario 4 & 31,421 & 45,373 & 65,107 & 92,777 & 30,236 & 43,661 & 62,650 & 89,276 \\
Productivity scenario 5 & 35,349 & 51,045 & 73,245 & 104,374 & 34,015 & 49,119 & 70,481 & 100,435 \\
\hline
\end{tabular}

Table 15. Demand 1 (Logistic): Total Medical Technologist (Unit: persons)

\begin{tabular}{lcccccccc}
\hline Working days (Active) & \multicolumn{9}{c}{255 days } \\
\hline Year & 2015 & 2020 & 2025 & 2030 & 2015 & 2020 & 2025 & 2030 \\
Productivity scenario 1 & 25,539 & 39,170 & 59,536 & 89,404 & 24,575 & 37,692 & 57,289 & 86,031 \\
Productivity scenario 2 & 27,860 & 42,731 & 64,948 & 97,532 & 26,809 & 41,119 & 62,497 & 93,852 \\
Productivity scenario 3 & 30,646 & 47,004 & 71,443 & 107,285 & 29,490 & 45,230 & 68,747 & 103,237 \\
Productivity scenario 4 & 34,051 & 52,227 & 79,381 & 119,206 & 32,766 & 50,256 & 76,386 & 114,708 \\
Productivity scenario 5 & 38,308 & 58,755 & 89,304 & 134,107 & 36,862 & 56,538 & 85,934 & 129,046 \\
\hline
\end{tabular}

Table 16. Demand 1 (Logarithm): Total Medical Technologist (Unit: persons)

\begin{tabular}{lcccccccc}
\hline Working days (Active) & \multicolumn{9}{c}{255 days } \\
\hline Year & 2015 & 2020 & 2025 & 2030 & 2015 & 2020 & 2025 & 2030 \\
Productivity scenario 1 & 22,801 & 29,879 & 37,567 & 45,634 & 21,940 & 28,751 & 36,150 & 43,912 \\
Productivity scenario 2 & 24,874 & 32,595 & 40,982 & 49,783 & 23,935 & 31,365 & 39,436 & 47,904 \\
Productivity scenario 3 & 27,361 & 35,854 & 45,081 & 54,761 & 26,329 & 34,501 & 43,380 & 52,695 \\
Productivity scenario 4 & 30,401 & 39,838 & 50,090 & 60,846 & 29,254 & 38,335 & 48,200 & 58,550 \\
Productivity scenario 5 & 34,201 & 44,818 & 56,351 & 68,451 & 32,911 & 43,127 & 54,224 & 65,868 \\
\hline
\end{tabular}

(Table 14). 둘째, Curve Estimation 방법 중 로짓함수모형을 적 용하여 추정한 수요추계결과를 살펴보면, 생산성에 따라 2015 년에 적게는 25,539 명에서 많게는 38,308 명이 필요할 것으로 전망되었고, 2030년에는 적게는 89,404명에서 많게는 134,107 명이 필요할 것으로 전망되었다(Table 15). 셋째, Logarithm모 형으로 추정한 수요추계결과를 살펴보면, 생산성에 따라 2015 년에 적게는 22,801 명에서 많게는 34,201 명이 필요할 것으로 전망되었고, 2030년에는 적게는 45,634명에서 많게는 68,451 명이 필요할 것으로 전망되었다(Table 16). 넷째, ARIMA모형 으로 추정한 수요추계결과를 살펴보면, 생산성에 따라 2015년
에 적게는 22,021명에서 많게는 33,032 명이 필요할 것으로 전 망되었고, 2030년에는 적게는 37,745 명에서 많게는 56,617명 이 필요할 것으로 전망되었다(Table 17). 한편 시나리오와는 무 관하게 진료가능일수를 265일을 기준으로 하면 255일에 비해 필요임상병리사수가 $3.8 \%$ 정도 줄어드는 것으로 나타났다.

\section{3. 인력수급비교 분석}

\section{1) 평균증가율}

평균증가율을 적용한 수요시나리오 하에서 진료일수 시나리 오와 생산성의 시나리오에 따라 임상병리사는 2015년에 68명 
Table 17. Demand 1 (ARIMA): Total Medical Technologist (Unit: persons)

\begin{tabular}{lcccccccc}
\hline Working days (Active) & \multicolumn{9}{c}{255} & days & \multicolumn{3}{c}{265 days } \\
\hline Year & 2015 & 2020 & 2025 & 2030 & 2015 & 2020 & 2025 & 2030 \\
Productivity scenario 1 & 22,021 & 27,657 & 33,000 & 37,745 & 21,190 & 26,613 & 31,755 & 36,321 \\
Productivity scenario 2 & 24,023 & 30,171 & 36,000 & 41,176 & 23,117 & 29,033 & 34,642 & 39,622 \\
Productivity scenario 3 & 26,425 & 33,188 & 39,600 & 45,294 & 25,428 & 31,936 & 38,106 & 43,585 \\
Productivity scenario 4 & 29,362 & 36,876 & 44,000 & 50,327 & 28,254 & 35,484 & 42,340 & 48,427 \\
Productivity scenario 5 & 33,032 & 41,485 & 49,500 & 56,617 & 31,785 & 39,920 & 47,632 & 54,481 \\
\hline
\end{tabular}

Table 18. Demand scenario 1: Applied by increased rate of geometric average (Unit: persons)

\begin{tabular}{|c|c|c|c|c|c|c|c|c|}
\hline \multirow{3}{*}{$\begin{array}{l}\text { Demand method } \\
\text { Working days } \\
\text { Year }\end{array}$} & \multicolumn{8}{|c|}{ Demand scenario 1: Applied by increased rate of geometric average } \\
\hline & \multicolumn{4}{|c|}{255} & \multicolumn{4}{|c|}{265} \\
\hline & 2015 & 2020 & 2025 & 2030 & 2015 & 2020 & 2025 & 2030 \\
\hline \multicolumn{9}{|l|}{ Supply } \\
\hline Licensed & 53,988 & 69,190 & 84,770 & 100,354 & 53,988 & 69,190 & 84,770 & 100,354 \\
\hline Available & 43,986 & 58,238 & 71,240 & 82,107 & 43,986 & 58,238 & 71,240 & 82,107 \\
\hline Activity (A) & 25,776 & 34,128 & 41,747 & 48,115 & 25,776 & 34,128 & 41,747 & 48,115 \\
\hline \multicolumn{9}{|l|}{ Demand (B) } \\
\hline Productivity scenario 1 & 23,566 & 34,030 & 48,830 & 69,583 & 22,677 & 32,746 & 46,988 & 66,957 \\
\hline Productivity scenario 2 & 25,708 & 37,124 & 53,269 & 75,908 & 24,738 & 35,723 & 51,259 & 73,044 \\
\hline Productivity scenario 3 & 28,279 & 40,836 & 58,596 & 83,499 & 27,212 & 39,295 & 56,385 & 80,348 \\
\hline Productivity scenario 4 & 31,421 & 45,373 & 65,107 & 92,777 & 30,236 & 43,661 & 62,650 & 89,276 \\
\hline Productivity scenario 5 & 35,349 & 51,045 & 73,245 & 104,374 & 34,015 & 49,119 & 70,481 & 100,435 \\
\hline \multicolumn{9}{|l|}{ Difference $(A-B)$} \\
\hline Productivity scenario 1 & 2,210 & 98 & $-7,083$ & $-21,468$ & 3,099 & 1,382 & $-5,241$ & $-18,842$ \\
\hline Productivity scenario 2 & 68 & $-2,996$ & $-11,522$ & $-27,793$ & 1,038 & $-1,595$ & $-9,512$ & $-24,929$ \\
\hline Productivity scenario 3 & $-2,503$ & $-6,708$ & $-16,849$ & $-35,384$ & $-1,436$ & $-5,167$ & $-14,638$ & $-32,233$ \\
\hline Productivity scenario 4 & $-5,645$ & $-11,246$ & $-23,360$ & $-44,662$ & $-4,460$ & $-9,533$ & $-20,903$ & $-41,161$ \\
\hline Productivity scenario 5 & $-9,573$ & $-16,917$ & $-31,498$ & $-56,259$ & $-8,239$ & $-14,991$ & $-28,734$ & $-52,320$ \\
\hline
\end{tabular}

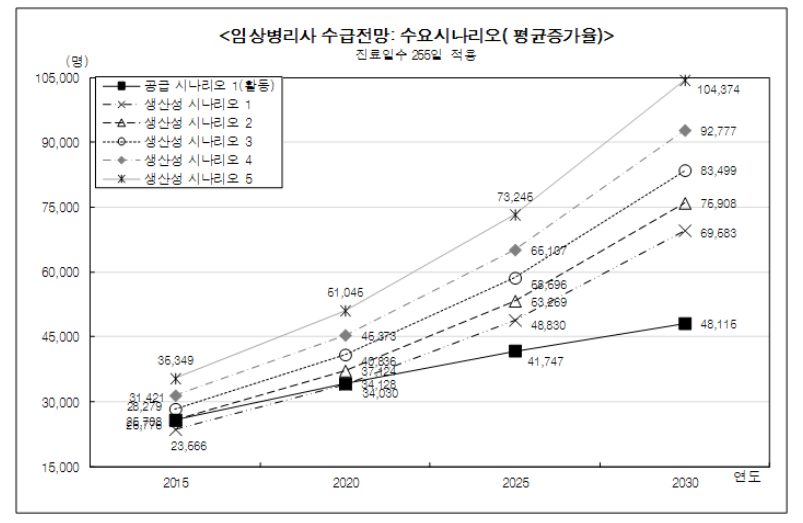

Figure 3. Demand Scenario 1: Applied by increased rate of geometric average-255 working days.

3,099 명의 공급과잉에서 1,436 명 9,573명의 공급부족 현상 이, 그리고 2030년에는 18,842명 56,259명의 공급부족 현상 까지 다양한 수급전망을 보이고 있다. 2012년 생산성을 기준으 로 한 ‘생산성 시나리오3' 하에서는 진료일수에 따라 임상병리 사는 2015년에 1,436명 2,503명의 공급부족 현상이 전망되

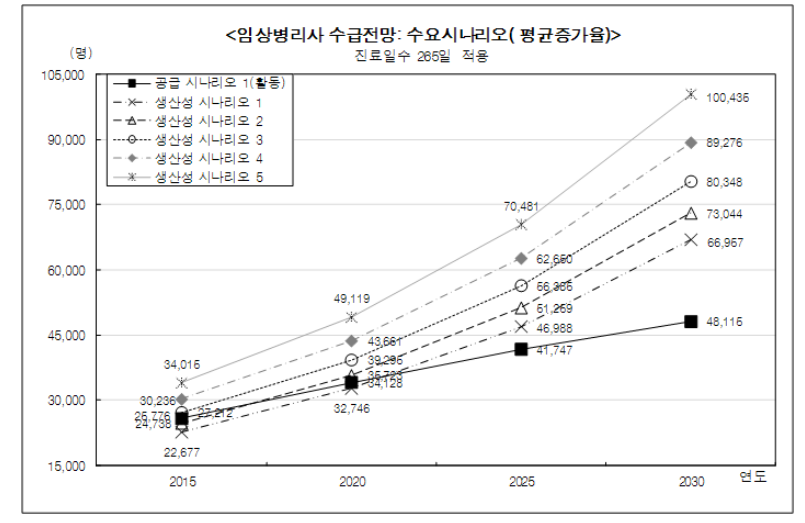

Figure 4. Demand Scenario 1: Applied by increased rate of geometric average-265 working days.

고 그리고 2030년에는 32,233명 35,384명의 공급부족현상 이 전망된다(Table 18, Figure 3, 4).

\section{2) Logistic 모형}

로짓모델을 적용한 수요시나리오 하에서 진료일수 시나리오 
Table 19. Demand scenario 2: Logistic (Units: days, persons)

\begin{tabular}{|c|c|c|c|c|c|c|c|c|}
\hline \multirow{3}{*}{$\begin{array}{l}\text { Demand method } \\
\text { Working days } \\
\text { Year }\end{array}$} & \multicolumn{8}{|c|}{ Demand scenario 2: Logistic } \\
\hline & \multicolumn{4}{|c|}{255} & \multicolumn{4}{|c|}{265} \\
\hline & 2015 & 2020 & 2025 & 2030 & 2015 & 2020 & 2025 & 2030 \\
\hline \multicolumn{9}{|l|}{ Supply } \\
\hline Licensed & 53,988 & 69,190 & 84,770 & 100,354 & 53,988 & 69,190 & 84,770 & 100,354 \\
\hline Available & 43,986 & 58,238 & 71,240 & 82,107 & 43,986 & 58,238 & 71,240 & 82,107 \\
\hline Activity (A) & 25,776 & 34,128 & 41,747 & 48,115 & 25,776 & 34,128 & 41,747 & 48,115 \\
\hline \multicolumn{9}{|l|}{ Demand (B) } \\
\hline Productivity scenario 1 & 25,539 & 39,170 & 59,536 & 89,404 & 24,575 & 37,692 & 57,289 & 86,031 \\
\hline Productivity scenario 2 & 27,860 & 42,731 & 64,948 & 97,532 & 26,809 & 41,119 & 62,497 & 93,852 \\
\hline Productivity scenario 3 & 30,646 & 47,004 & 71,443 & 107,285 & 29,490 & 45,230 & 68,747 & 103,237 \\
\hline Productivity scenario 4 & 34,051 & 52,227 & 79,381 & 119,206 & 32,766 & 50,256 & 76,386 & 114,708 \\
\hline Productivity scenario 5 & 38,308 & 58,755 & 89,304 & 134,107 & 36,862 & 56,538 & 85,934 & 129,046 \\
\hline \multicolumn{9}{|l|}{ Difference $(A-B)$} \\
\hline Productivity scenario 1 & 238 & $-5,042$ & $-17,789$ & $-41,290$ & 1,201 & $-3,564$ & $-15,542$ & $-37,916$ \\
\hline Productivity scenario 2 & $-2,084$ & $-8,603$ & $-23,201$ & $-49,417$ & $-1,033$ & $-6,991$ & $-20,751$ & $-45,737$ \\
\hline Productivity scenario 3 & $-4,870$ & $-12,876$ & $-29,696$ & $-59,171$ & $-3,714$ & $-11,103$ & $-27,000$ & $-55,122$ \\
\hline Productivity scenario 4 & $-8,275$ & $-18,099$ & $-37,634$ & $-71,091$ & $-6,990$ & $-16,128$ & $-34,639$ & $-66,593$ \\
\hline Productivity scenario 5 & $-12,532$ & $-24,628$ & $-47,557$ & $-85,992$ & $-11,086$ & $-22,410$ & $-44,187$ & $-80,931$ \\
\hline
\end{tabular}

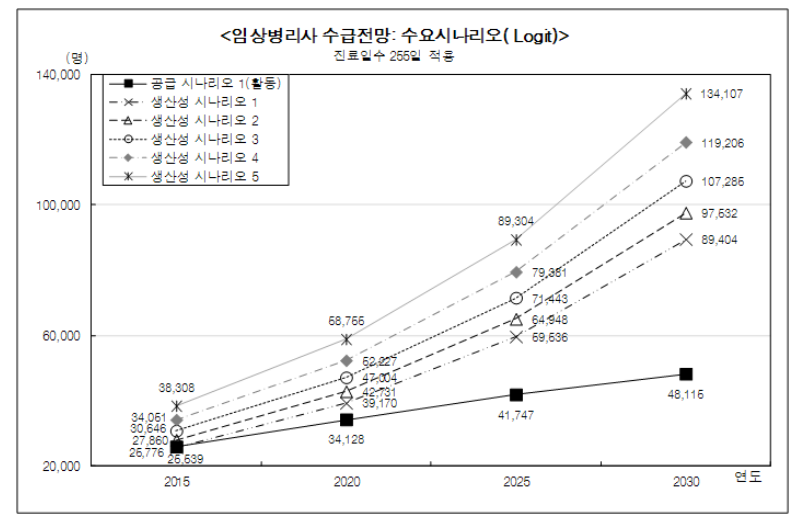

Figure 5. Demand Scenario 2: Logistic-255 working days.

와생산성의 시나리오에 따라 임상병리사는 2015년에 238명 1,210 명의 공급과잉에서 1,033 명 12,532 명의 공급부족 현 상이, 그리고 시간이 지남에 따라 2030년에는 37,916명 85,992명의 공급부족이 전망되고 있다. 2012년 생산성을 기준 으로 한 '생산성 시나리오 3'하에서는 진료일수에 따라 임상병 리사는 2015년에 3,714명 4,870명의 공급부족이 전망되며, 2030년에는 55,122명 59,171명의 공급부족현상이 전망된 다(Table 19, Figure 5, 6).

\section{3) Logarithm 모형}

로그함수를 적용한 수요시나리오 하에서 진료일수 시나리오 와 생산성의 시나리오에 따라 임상병리사는 2015년에 902명 3,836 명의 공급과잉에서 552 명 8,425 명의 공급부족 현상이, 그리고 2030년에는 211명 4,203명의 공급과잉에서 1,668

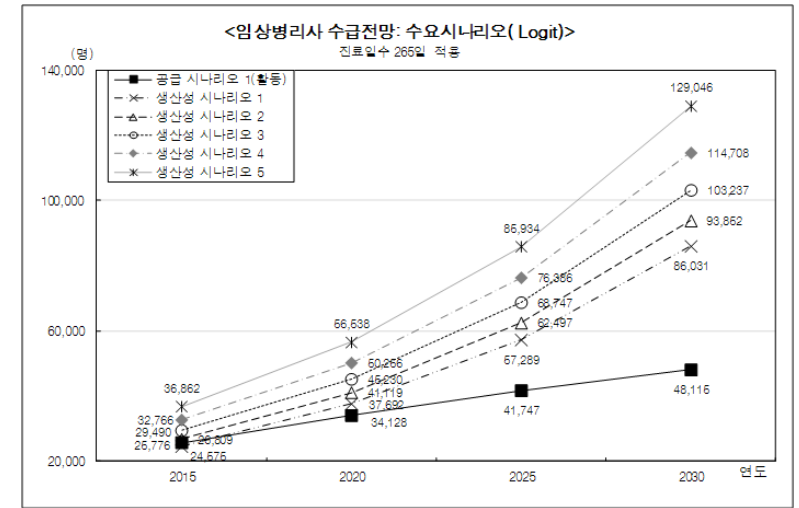

Figure 6. Demand Scenario 2: Logistic-265 working days.

명 20,337명의 공급부족 현상까지 다양한 수급전망을 보이고 있다. 2012년 생산성을 기준으로 한 '생산성 시나리오 3' 하에 서는 진료일수에 따라 임상병리사는 2015년에 552명 1,585 명의 공급부족 현상이 전망되고 그리고 2030년에는 4,580명 6,646 명의 공급부족현상이 전망된다(Table 20 , Figure 7,8 ).

\section{4) ARIMA 모형}

ARIMA모델을 적용한 수요시나리오 하에서 진료일수 시나 리오와 생산성의 시나리오에 따라 임상병리사는 2015년에 348 명 4,586명의 공급과잉에서 649 명 7,256명의 공급부 족 현상이, 그리고 2030 년에는 2,821명 11,794 명의 공급과 잉에서 313명 8,503명의 공급부족 현상까지 다양한 수급전 망을 보이고 있다. 2012년 생산성을 기준으로 한 '생산성 시나 리오 3' 하에서는 진료일수에 따라 임상병리사는 2015년에 
Table 20. Demand scenario 3: Logarithm (Units : days, persons)

\begin{tabular}{|c|c|c|c|c|c|c|c|c|}
\hline \multirow{3}{*}{$\begin{array}{l}\text { Demand method } \\
\text { Working days } \\
\text { Year }\end{array}$} & \multicolumn{8}{|c|}{ Demand scenario 3: Logarithm } \\
\hline & \multicolumn{4}{|c|}{255} & \multicolumn{4}{|c|}{265} \\
\hline & 2015 & 2020 & 2025 & 2030 & 2015 & 2020 & 2025 & 2030 \\
\hline \multicolumn{9}{|l|}{ Supply } \\
\hline Licensed & 53,988 & 69,190 & 84,770 & 100,354 & 53,988 & 69,190 & 84,770 & 100,354 \\
\hline Available & 43,986 & 58,238 & 71,240 & 82,107 & 43,986 & 58,238 & 71,240 & 82,107 \\
\hline Activity (A) & 25,776 & 34,128 & 41,747 & 48,115 & 25,776 & 34,128 & 41,747 & 48,115 \\
\hline \multicolumn{9}{|l|}{ Demand (B) } \\
\hline Productivity scenario 1 & 22,801 & 29,879 & 37,567 & 45,634 & 21,940 & 28,751 & 36,150 & 43,912 \\
\hline Productivity scenario 2 & 24,874 & 32,595 & 40,982 & 49,783 & 23,935 & 31,365 & 39,436 & 47,904 \\
\hline Productivity scenario 3 & 27,361 & 35,854 & 45,081 & 54,761 & 26,329 & 34,501 & 43,380 & 52,695 \\
\hline Productivity scenario 4 & 30,401 & 39,838 & 50,090 & 60,846 & 29,254 & 38,335 & 48,200 & 58,550 \\
\hline Productivity scenario 5 & 34,201 & 44,818 & 56,351 & 68,451 & 32,911 & 43,127 & 54,224 & 65,868 \\
\hline \multicolumn{9}{|l|}{ Difference $(A-B)$} \\
\hline Productivity scenario 1 & 2,975 & 4,249 & 4,180 & 2,481 & 3,836 & 5,377 & 5,597 & 4,203 \\
\hline Productivity scenario 2 & 902 & 1,533 & 764 & $-1,668$ & 1,841 & 2,763 & 2,311 & 211 \\
\hline Productivity scenario 3 & $-1,585$ & $-1,727$ & $-3,334$ & $-6,646$ & -552 & -374 & $-1,633$ & $-4,580$ \\
\hline Productivity scenario 4 & $-4,625$ & $-5,710$ & $-8,343$ & $-12,731$ & $-3,478$ & $-4,207$ & $-6,453$ & $-10,435$ \\
\hline Productivity scenario 5 & $-8,425$ & $-10,690$ & $-14,604$ & $-20,337$ & $-7,135$ & $-8,999$ & $-12,478$ & $-17,754$ \\
\hline
\end{tabular}

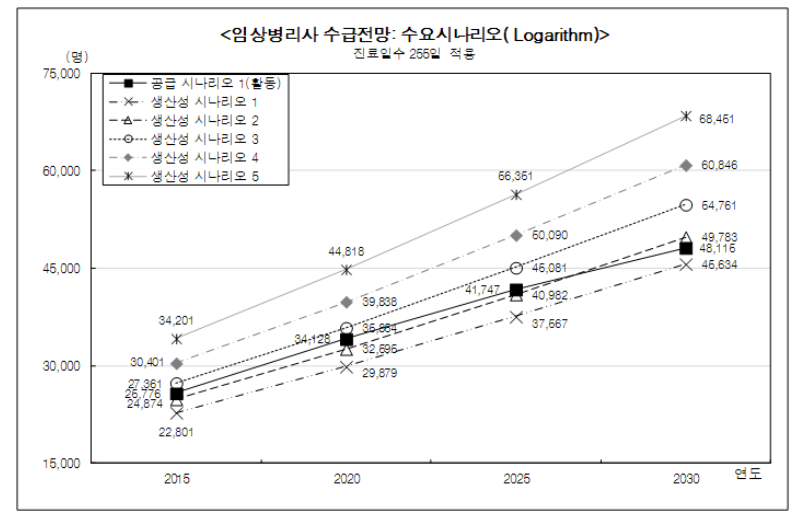

Figure 7. Demand Scenario 3: Logarithm-255 working days.

348 명의 공급과잉에서 649 명의 공급부족 현상까지 다양한 수 급전망을 보이고, 2030년에는 2,821명 4,530명의 공급과잉 현상이 전망된다(Table 21, Figure 9, 10).

수급비교결과 수급불균형의 방향과 정도는 임상병리사 인력 수요추계에 사용한 의료이용증가율, 진료가능일수, 임상병리 사 생산성 생산성은 정부의 정책과 밀접한 관련이 있으므로 이 시점에서는 정부의 정책방향이 고려되지 않은 현재 생산성을 기준으로 비교하였다[1].

\section{고 찰}

앞선 수급비교결과에 따른 수급전망에 의하면, 생산성의 시 나리오에 따라 임상병리사의 공급이 과잉되기도 하고 부족하기 도 할 것으로 전망되었다. 이렇게 임상병리사수급 비교 결과는

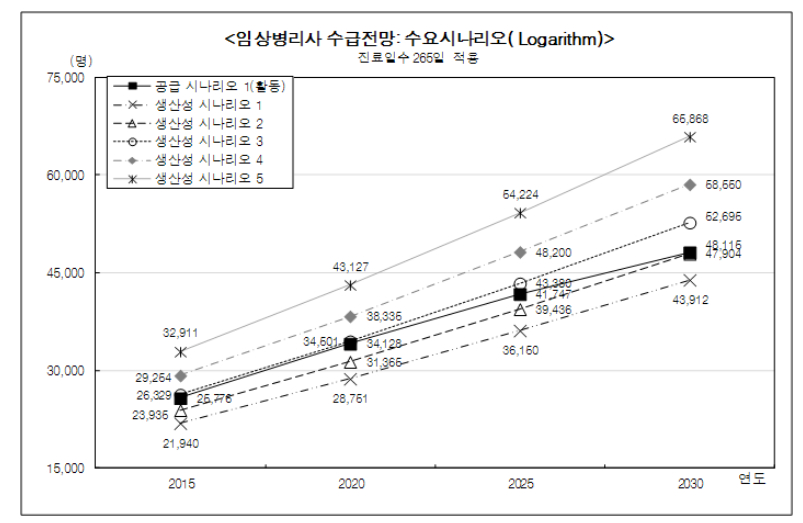

Figure 8. Demand Scenario 3: Logarithm-265 working days.

임상병리사 생산성 가정에 따라 달라지지만, 어느 시나리오를 선택할 것인가는 궁극적으로 정부의 정책방향에 따라 달라진 다. 이에 본 연구에서 수급비교결과 수급불균형의 방향과 정도 는 임상병리사의 생산성과 임상병리검사건수 추세의 시나리오 에 따라 임상병리사 수급의 결과가 달라진다. 임상병리검사건 수 증감률 시나리오는 과거 10년간의 증가 추세를 인위적으로 가정한 로그함수를 적용한 시나리오 보다는 시계열분석에서 ARIMA모델을 적용한 모델이 적합하다고 판단된다. 따라서 ARIMA 모델을 적용한 수요시나리오를 중심으로 2012년 현재 의 임상병리사의 생산성을 기준으로 보면, 근무일수에 따라 2030년에는 2,821 4,530명의 임상병리사 공급이 과잉될 것 으로 전망된다.

국민소득의 증대와 생활수준의 향상, 의료기술의 발전, 인구 구조의 변화 등으로 국민들의 건강에 대한 기대의 상승과 함께 
Table 21. Demand scenario 4: ARIMA (Units: days, persons)

\begin{tabular}{|c|c|c|c|c|c|c|c|c|}
\hline \multirow{3}{*}{$\begin{array}{l}\text { Demand method } \\
\text { Working days } \\
\text { Year }\end{array}$} & \multicolumn{8}{|c|}{ Demand scenario 4: ARIMA } \\
\hline & \multicolumn{4}{|c|}{255} & \multicolumn{4}{|c|}{265} \\
\hline & 2015 & 2020 & 2025 & 2030 & 2015 & 2020 & 2025 & 2030 \\
\hline \multicolumn{9}{|l|}{ Supply } \\
\hline Licensed & 53,988 & 69,190 & 84,770 & 100,354 & 53,988 & 69,190 & 84,770 & 100,354 \\
\hline Available & 43,986 & 58,238 & 71,240 & 82,107 & 43,986 & 58,238 & 71,240 & 82,107 \\
\hline Activity (A) & 25,776 & 34,128 & 41,747 & 48,115 & 25,776 & 34,128 & 41,747 & 48,115 \\
\hline \multicolumn{9}{|l|}{ Demand (B) } \\
\hline Productivity scenario 1 & 22,021 & 27,657 & 33,000 & 37,745 & 21,190 & 26,613 & 31,755 & 36,321 \\
\hline Productivity scenario 2 & 24,023 & 30,171 & 36,000 & 41,176 & 23,117 & 29,033 & 34,642 & 39,622 \\
\hline Productivity scenario 3 & 26,425 & 33,188 & 39,600 & 45,294 & 25,428 & 31,936 & 38,106 & 43,585 \\
\hline Productivity scenario 4 & 29,362 & 36,876 & 44,000 & 50,327 & 28,254 & 35,484 & 42,340 & 48,427 \\
\hline Productivity scenario 5 & 33,032 & 41,485 & 49,500 & 56,617 & 31,785 & 39,920 & 47,632 & 54,481 \\
\hline \multicolumn{9}{|l|}{ Difference $(A-B)$} \\
\hline Productivity scenario 1 & 3,755 & 6,471 & 8,747 & 10,370 & 4,586 & 7,514 & 9,992 & 11,794 \\
\hline Productivity scenario 2 & 1,753 & 3,957 & 5,747 & 6,939 & 2,660 & 5,095 & 7,105 & 8,492 \\
\hline Productivity scenario 3 & -649 & 939 & 2,147 & 2,821 & 348 & 2,192 & 3,641 & 4,530 \\
\hline Productivity scenario 4 & $-3,585$ & $-2,748$ & $-2,253$ & $-2,212$ & $-2,478$ & $-1,357$ & -593 & -313 \\
\hline Productivity scenario 5 & $-7,256$ & $-7,358$ & $-7,753$ & $-8,503$ & $-6,009$ & $-5,792$ & $-5,885$ & $-6,366$ \\
\hline
\end{tabular}

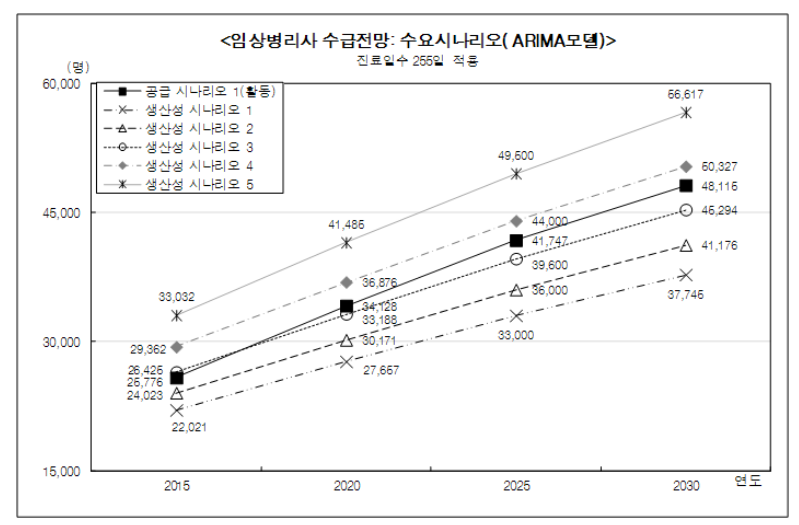

Figure 9. Demand Scenario 4: ARIMA-255 working days.

보건의료 수요는 크게 증가하여 왔다. 이에 따라 임상병리사에 대한 수요도 증가되어 왔으나, 최근 의료장비나 기기의 첨단화, 자동화로 인해 그 동안 임상병리사들이 해왔던 많은 작업들의 기계로의 대체는 임상병리사의 수요에 부정적인 영향을 미칠 것으로 보인다. 또한 인건비 절감을 위해 소규모의 병의원들이 임상병리검사를 전문 수탁검사기관에 의뢰하는 경우가 증가하 면서 이들 병의원에서의 임상병리사의 고용이 감소할 것으로 전망되고 있다. 대형병원의 경우, 자동화시스템을 도입하여 많 은 부분을 대신하게 함으로써 신규 수요가 감소할 것으로 전망 된다. 그러나 한편으로는 의료이용량의 증가와 새로운 유형의 임상검사가 개발됨에 따라 임상병리사에 대한 수요가 증가할 것으로 예상된다. 특히 건강에 대한 관심 증대로 인해 건강진단 에 대한 수요가 증가하고, 질병 가능성 사전 예측이 관심을 받으 면서 검진센터에 대한 수요 증가가 예상되므로 임상병리사에

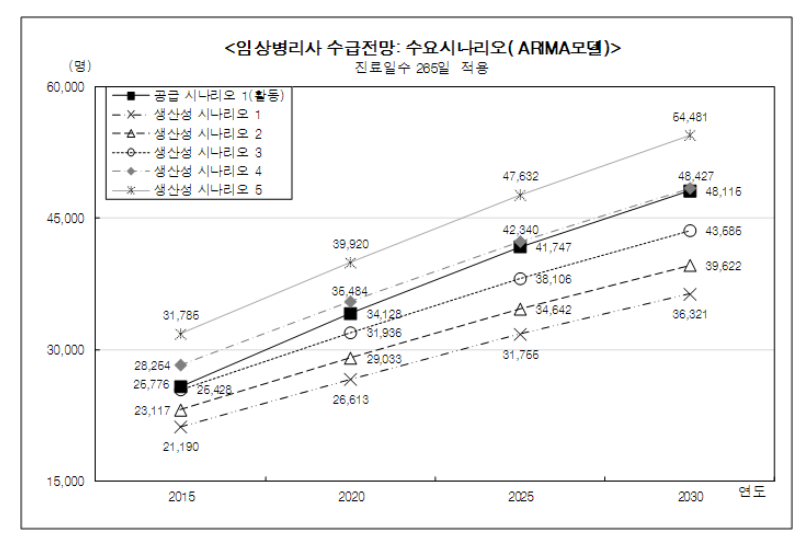

Figure 10. Demand Scenario 4: ARIMA-265 working days.

대한 새로운 요구가 발생될 것으로 보인다. 뿐만 아니라 유전자 에 대한 연구가 활발해지면서 유전자를 통한 친자확인이 관심 을 받고 있으며, 법의학관련 검사, 제대혈관련 실험실, 생명보험 회사의 심사업무 등에서도 임상병리사의 역할이 요구되고 있어 그 활동영역이 확대됨으로써 수요 증대에 긍정적인 영향으로 작용될 것이다. 소규모 병의원에서의 취업은 감소될 전망이지 만 병리검사를 수탁검사기관에 의뢰하는 경우가 늘어나고 있어 검사센터에서의 수요는 꾸준히 있을 것으로 예상된다[1]. 또한 2008년 노인장기요양보험제도의 도입으로 요양병원에서 필요 로 하는 인력으로 임상병리사가 꼽히고 있다. 그러나 여전히 많 은 요양병원에서 임상병리사가 없어 환자 입원시 필수인 ‘혈액 및 소변검사' 등이 전혀 이뤄지지 않고 있다고 한다[1]. 요양병 원협회 자료를 보면 2008년 12월 현재 전국 690개 요양병원에 상근 중인 임상병리사는 343 명(49.1\%)이다. 따라서 이들에 대 
한 수요도 증가할 것으로 전망된다. 그러므로 임상병리사 공급 부족과 수요전망에 따라 임상병리사의 공급을 증가시키는 정책 뿐만 아니라 가용인력 중에서 임상병리사사 취업률이 $60 \%$ 대인 점을 감안하면 미취업자를 활용하는 정책도 함께 고려해야한 다. 이러한 대책으로는 미취업인력에 대한 취업기회를 확대하 는 방향으로 나아가야 할 것이고, 이를 위해서는 보건소 검사실 의 기능강화 및 임상병리사 정원증원 및 신분보장, 통원치료 환 자를 위한 상설 검사체제 확립, 산업재해 분야 및 의원급 검사기 능 강화, 무면허 검사요원의 통제, 해외인력수출 확대 등이 필요 할 것으로 사료된다[1].

\section{요 약}

본 연구는 임상병리사 인력의 인력의 수급전망을 추계하여 인 력계획 수립에 필요한 정책자료를 제공하는 것을 목적으로 한다. 공급은 기초추계(baseline projection) 모형에 근거한 인구학적 방법(demographic method)을 이용하여 추계하였으며, 수요추 계는 임상병리사가 검사하는 임상병리검사 건수를 이용하는 의 료수요에 의한 방법을 적용하였다. 전반적인 임상병리사 인력수 급추계결과는 생산성의 시나리오에 따라 공급이 과잉되기도 하 고 부족하기도 할 것으로 전망되었다. 이렇게 임상병리사의 수급 비교 결과는 임상병리사의 생산성 가정에 따라 달라지지만, 어느 시나리오를 선택할 것인가는 궁극적으로 정부의 정책방향에 따 라 달라진다. 즉 임상병리사의 생산성을 현재보다 높게 채택하는 지 혹은 낮게 책정하는지는 보험재정 여건 등을 고려해야 하는 정 부 정책에 달려있는 것이다. 이에 본 연구에서 정부의 정책방향 이 고려되지 않은 2012년 현재의 생산성을 기준으로 한 '생산성 시나리오3'을 살펴보면, ARIMA모델을 적용한 수요시나리오를 중심으로 보면 근무일수에 따라 2030년에는 2821명에서 4,530 명의 임상병리사 공급이 과잉될 것으로 전망된다. 이러한 공급과 잉은 전체에서 차지하는 비중이 $10 \%$ 미만이기 때문에 크게 문제 가 되지 않을 것으로 판단된다. 그러나 임상병리사사 취업률이 $60 \%$ 대인 점을 감안하면 미취업자를 활용하는 정책도 함께 고려 해야한다. 이러한 대책으로는 미취업인력에 대한 취업기회를 확 대하는 방향으로 나아가야 할 것이고, 이를 위해서는 보건소 검 사실의 기능강화 및 임상병리사 정원증원 및 신분보장, 통원치료 환자를 위한 상설 검사체제 확립, 산업재해 분야 및 의원급 검사 기능 강화, 무면허 검사요원의 통제, 해외인력수출 확대 등이 필 요할 것으로 사료된다.

Acknowledgements: This paper is an excerpt, revision and supplementation of the research report of the mid-to long-term supply and demand estimation of the healthcare personnel: 2015 2030, conducted by the Korea health personnel licensing examination institute and the Korea institute for health and social affairs.

Conflict of interest: None

Author's information (Position): Oh Y, Researcher.

\section{REFERENCES}

1. Oh YH. Study on mid-to long-term supply and demand of healthcare workforce: 2015-2030. Sejong: Korea Institute for Health \& Social Affairs; 2014 Nov. Report No. RE01-1001-00.

2. Oh YH. The future requirements and supply of opticians in Korea. J Korean Ophthalmic Opt Soc. 2010;15:1-7.

3. Ray D. Indicators for the measurement of health manpower imbalances. World Health Stat Q. 1987;40:349-54.

4. Carver P. Self sufficiency and international medical graduatesAustralia. Melbourne: National Health Workforce Taskforce;2008.

5. Kim YS. A study on the supply and demand of medical staff in the short and long term II: Nurses, nursing assistants, pharmacists, medical staff (medical technologist, radiologists, physical therapists). Seoul: Korea Institute for Health \& Social Affairs; 1991. p154.

6. Oh YH. The present condition of supply and demand for medical technicians and management policy implications. Seoul: Korea Institute for Health \& Social Affairs; 2005 May. p111. Report No. 0405-PO00-0707-0001.

7. Oh YH. The demand and supply of registered nurses in Korea and policy recommendations. Seoul: Korea Institute for Health \& Social Affairs. 2008;28:68-86.

8. Confrey EA. The logic of a "shortage of health manpower". Int J Health Serv. 1973;3:253-259.

9. WHO. World health report 2003: Shaping the future. Geneva: WHO; 2003 [cited 2018 November 21]. Available from: https:// www.who.int/whr/2003/en/whr03_en.pdf?ua=1.

10. WHO. World health report 2008: Primary health care future. Geneva: WHO; 2008 [cited 2018 November 21]. Available from: http://apps.who.int/medicinedocs/documents/s22232en/ s22232en.pdf.

11. Oh YH. Medical supply mid-to-long-term estimation. Seoul: Korea Institute for Health \& Social Affairs; 2006 March. Report No. 2006-07.

12. Yu JY, Kim GW. The research on the medical tourism professionals operating features and specialization requirements. Journal of Tourism Sciences. 2013;37:175-196.

13. HRSA. Physican supply and demand: Projection to 2020. Rockville: HRSA; 2006 [cited 2018 November 21]. Available from: https://bhw.hrsa.gov/sites/default/files/bhw/nchwa/projections/ physician2020projections.pdf.

14. Kirkpatrick PJ, Tuner CL, smith C, Hutchinson PJ, Murray GD. Simvastatin in aneurysmal subarachnoid haemorrhage (STASH): 
a multicentre randomised phase 3 trial. Lancet Neurol. 2014; 13:666-675.

15. Hanke JE, Wichern DW. Business forecasting. 9th ed. New york: Prentice Hall; 2008.

16. Park HA, Choi JS, Ryu SW. A study on the supply and demand of medical staff in the short and long term: Physician, dentist, oriental medicine, dental technician, dental hygienist. Seoul: Korea Institute for Health \& Social Affairs. 1990 Dec. p113.

17. Moon HS. A study on the busyness of practicing dentists in the republic of Korea. J Korean Acad Oral Health. 1994;18:339-366. 